\title{
STUDY OF THE START-UP OF AN UPFLOW LABORATORY-SCALE ANAEROBIC SLUDGE BLANKET FOR THE TREATMENT OF SLAUGHTERHOUSE WASTEWATER
}

\author{
MARTHA N. CHOLLOM ${ }^{1}$, SUDESH RATHILAL ${ }^{1}$, FEROZ M. SWALAHA ${ }^{2}$, \\ BABATUNDE F. BAKARE ${ }^{3}$ \& EMMANUEL KWEINOR TETTEH ${ }^{1}$ \\ ${ }^{1}$ Faculty of Engineering and the Built Environment, Department of Chemical Engineering, \\ Durban University of Technology, South Africa \\ ${ }^{2}$ Faculty of Applied science, Department of Biotechnology and Food Technology, \\ Durban University of Technology, South Africa \\ ${ }^{3}$ Faculty of Engineering, Department of Chemical Engineering, \\ Mangosuthu University of Technology, South Africa
}

\section{ABSTRACT}

The upflow anaerobic sludge blanket (UASB) process is a low-cost and low-skill requirement technology for reducing organic pollution loads especially for industries producing effluents in developing economies. A laboratory-scale UASB reactor was used for the treatment of slaughterhouse wastewater with the aim of studying its performance efficiency. The UASB reactor was seeded with digested sludge from a local water treatment plant treating domestic wastewater. Parameters such as $\mathrm{pH}$, chemical oxygen demand (COD), biochemical oxygen demand (BOD), total suspended solids (TSS), volatile suspended solids (VSS) and volume of biogas generated during the digestion process were evaluated. The hydraulic retention time (HRT) was maintained at $12 \mathrm{hr}$ while the organic loading rates were varied from $0.2-1.4 \mathrm{~kg} \mathrm{COD} /\left(\mathrm{m}^{3} \cdot \mathrm{d}^{-1}\right)$. The reactor was operated under mesophilic conditions. At the early stage of the start-up of the reactor, (COD) and (BOD) removal were in the range of $30-62 \%$. The UASB reactor performed better at an organic loading rate (OLR) of $0.8 \mathrm{~kg} \mathrm{COD} /\left(\mathrm{m}^{3} \cdot \mathrm{d}^{-1}\right)$ with a COD removal of $86 \%$ as compared to the OLRs used in this experiment.

Keywords: anaerobic digestion, slaughterhouse wastewater, start-up, chemical oxygen demand, organic loading rate, biogas, up-flow anaerobic reactor, hydraulic retention time.

\section{INTRODUCTION}

There is a continuous increase in the demand for meat production as the demand for protein increases. This increase is attributed to the increase in the world population. Meat production processes entails the consumption of huge amounts of water and in return increased pollution. The large consumption of water is for process operations such as slaughtering and cleaning and other housekeeping practises. This therefore entails that effluents from the slaughter houses are contaminated with blood, fats, manure, urine, meat tissue and other substances, leading to high organic strength, sufficient organic biological nutrients and adequate alkalinity. Pollution from meat production can be as a result of failure to adhere to good manufacturing practices and good hygiene practices [1]. According to a study by Gerber et al. [1] and Kundu et al. [2], the blood from the slaughter house wastewater has the highest chemical oxygen demand (COD). They further stated that if the blood from a single cow carcass is allowed to be discharged directly into a sewer line without treatment, the effluent load would be an equivalent to the total sewage produced by 50 people on an average day.

The effluent therefore, if discharged untreated into receiving water bodies, will cause a serious environmental problem such as odour generation, algal bloom and eutrophication especially from the nitrogenous compounds in the wastewater [2]. Treatment of wastewater 
from a slaughterhouse could involve mainly physical, biological and chemical methods depending on the characteristics of the wastewater. Physical and chemical methods are used as preliminary treatment before the biological process. The reason is to provide a degree of purification of the wastewater with a better final effluent quality to be able to meet the stricter environmental requirements and also to reduce the negative impact of the high loading rate and fat content on biological processes [1].

Biological treatment processes are capable of converting the organic matter in the wastewater to compounds such as ammonia and phosphorous which can be used as fertilizers. For anaerobic biological processes, the production of methane gas as an additional source of energy has shown to be even more advantageous when compared to other process. They are recommended for the treatment of high strength polluted wastewater like that from the slaughter houses. However, for its successful application, good process control must be ensured [3], [4].

Over the years, several anaerobic digestion (AD) processes have emerged for the treatment of high strength wastewater. Amongst all however, the upflow anaerobic sludge blanket reactor (UASB) have received the most attention due to its ability to treat high strength wastewater at a higher organic loading rate (OLR) and a lower retention time (HRT). Other features which make the UASB an attractive technology includes; simple design, easy construction and maintenance, low operating cost, high removal efficiency, stability and low energy demand and most important, the production of biogas during the digestion processes [3]. There has been various research on anaerobic processes, for example Babaee and Shayegan [5] studied the production of biogas from vegetable wastes using an anaerobic digestion process and came to a conclusion that anaerobic digestion represents a feasible and effective method to convert the solid organic waste to biogas fuel.

Biogas generation from various processes has found a wide range of applications. It has been used domestically and industrially for cooking, lighting, heating, crop drying, running refrigerators, water pumps and generators to mention but a few [6].

Other countries have tapped into the benefit of this technology and some are already using the energy produced during the process to augment for energy consumption within the plants. South Africa and the rest of Africa are yet to fully utilise this technology. The treatment of pollutants at the source has been recommended for most manufacturing industries rather than sending to the public treatment water works where this wastewater mixes up with other waste. This becomes difficult to treat due to the complexity of the mixed wastewater [3], [7].

The study presented here aims to use anaerobic digestion for the treatment of slaughterhouse wastewater by varying the organic loading rate and monitoring the performance efficiency of the reactor with respect to contaminant removal and biogas production.

\section{MATERIALS AND METHOD}

\subsection{Physiochemical properties of seed sludge and wastewater}

Digested sludge was obtained from a wastewater treatment plant with a capacity to treat domestic wastewaters. The wastewater was obtained from a local abattoir that slaughters swine only. The following physico-chemical properties were determined: chemical oxygen demand (COD), biological oxygen demand (BOD), total suspended solids (TSS), volatile suspended solids (VSS), total solids (TS), total dissolved solids (TDS), $\mathrm{pH}$, nitrites $\left(\mathrm{NO}_{2}\right.$ ), nitrates $\left(\mathrm{NO}_{3}\right)$ and nitrogen/ammonia $\left(\mathrm{N} / \mathrm{NH}_{3}\right)$. Parameters were determined following the standard methods for the examination of water and wastewater [8]. 
The feed and treated effluent were analysed for the parameters mentioned above. Samples were collected from the influent, effluent and sampling ports along the reactor. Analyses of samples were replicated to ensure the quality of experiments. Biogas was collected by the water displacement method. The water in the gas collector was acidified with sulphuric acid for the dissolution of carbon dioxide

The organic loads removal efficiency of the UASB reactor was calculated using eqn (1).

$$
\text { Removal Efficiency }=\frac{\mathrm{C}_{\text {influent }}-\mathrm{C}_{\text {effluent }}}{\mathrm{C}_{\text {influent }}} * 100 \%,
$$

where, $\mathrm{C}_{\text {influent }}=$ initial parameter concentration and $\mathrm{C}_{\text {effluent }}=$ final parameter concentration.

\subsection{Analytical techniques}

The TS and TSS were determined gravimetrically by drying well homogenized samples respectively at $103^{\circ} \mathrm{C}$ for $24 \mathrm{~h}$. The VSS fractions were determined gravimetrically b incineration in a muffle furnace at $550^{\circ} \mathrm{C}$ for $1 \mathrm{~h}$ [8]. The $\mathrm{pH}$ and temperature were measured using a $\mathrm{pH}$ meter and thermometer respectively. The $\mathrm{BOD}_{5}$ measurement was done using the respirometric method for five days (OxiTop TS 606/2-i system). $\mathrm{NH}_{3}, \mathrm{NO}_{2}$ and $\mathrm{NO}_{3}$ were measured using a Thermo Gallery photometric analyser (Thermo Scientific, UK). COD was determined using close refluxing according to the standard method 5220D [8].

\subsection{Design of the reactor}

The reactor used for this study was a laboratory bench scale UASB reactor (Fig. 1). The reactor volume was 33 litres, but only a working volume of 10 litres was considered. The setup consisted of a two peristaltic pump for feeding and effluent collection, influent and effluent tank, topped with a gas-solid-liquid separator for gas collection. The reactor was operated at a mesophilic temperature $\left(24-35^{\circ} \mathrm{C}\right)$. The influent pump was timed to supply 5.2 litres of feed to the reactor daily.

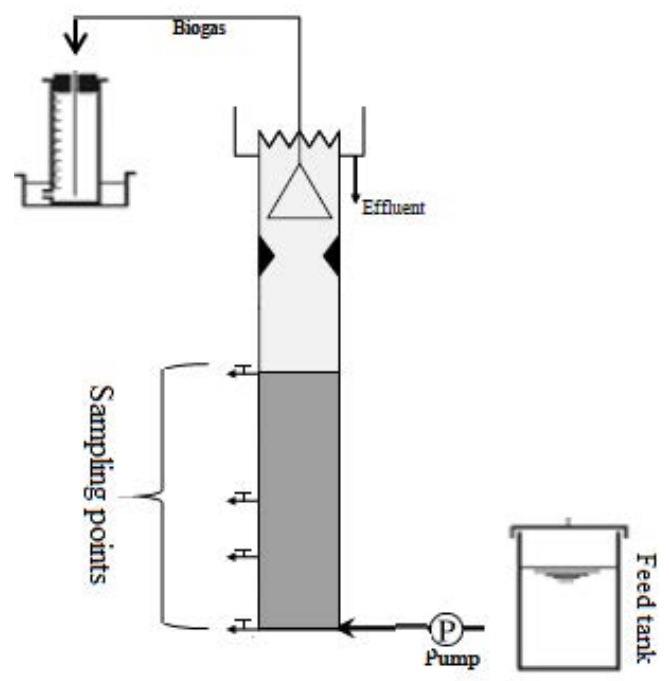

Figure 1: Schematic diagram for the experimental setup. 


\subsection{Operational and performance parameters}

The reactor was inoculated with seed sludge from a UASB reactor of a wastewater treatment plant. The amount of sludge added to the reactor was $3.5 \mathrm{~L}$, about one third of the total working volume. It was operated batch wise for the first four days of start-up and continued with semi batch operation until its stabilisation. A hydraulic retention time (HRT) of 12 hours was used and three organic loads were considered; $0.2,0.8$ and $1.4 \mathrm{~kg} \mathrm{COD} /\left(\mathrm{m}^{3} \cdot \mathrm{d}^{-1}\right)$. Each loading was considered for more than two weeks before changing to the next. OLR is defined as the mass of the pollutant introduced in a unit volume of a UASB per unit time, therefore it takes into account the liquid flowrate and contamination load and this is an important factor for the reactor and operational characteristic [4], [6], [9]. OLR calculation is expressed in eqn (2).

$$
O L R=Q \cdot \frac{C}{V}
$$

where, OLR is the volumetric organic loading rate $\left(\mathrm{kg} \mathrm{COD} \mathrm{m}^{-3} \cdot \mathrm{d}^{-1}\right)$, Q the influent flow rate

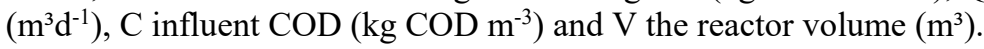

\section{RESULTS AND DISCUSSION}

\subsection{Reactor start-up}

The start-up period of the reactor is considered to be very important and it is dependent on the population of the microorganisms. Factors such as type of inoculum, strength and type of wastewater, the level of volatile acids, temperature and $\mathrm{pH}$ play vital roles during start-up [10]. Fig. 2 shows the daily recordings of $\mathrm{pH}$ and temperature of the UASB reactor. Temperature was measured daily in the UASB reactors inlet and outlet which was maintained between $24-35^{\circ} \mathrm{C}$ through the constant recirculation of water using a water bath. Temperature has a significant effect on either methanogens metabolisms or biochemical reaction rates. A high temperature can produce irreversible damage on biological structure of methanogens thus affecting general performance of the system [4], [11]. According to Chernicharo [4], biological systems are affected by temperature by influencing the enzymatic reaction rates and influencing substrate diffusion rates. Therefore the goal of the daily temperature measurement was to ensure that the UASB was within the mesophilic range.

Similarly, $\mathrm{pH}$ was monitored through the inlet and outlet ports of the reactor for alkalinity of the system. The alkalinity of the reactor was maintained by the addition of $\mathrm{NaHCO}_{3}$ when a drop in $\mathrm{pH}$ was observed. The outlet $\mathrm{pH}$ was in the range $7-7.7$, except for the $28^{\text {th }}$ day as shown in Fig. 2. This was an indication that an active metabolism was occurring by the methanogens bacteria. Literature has shown that $\mathrm{pH}$, alkalinity and volatile acids are important factors that need to be monitored during AD processes [4]. Chernicharo [4] in his study stated that $\mathrm{pH}$ can affect $\mathrm{AD}$ directly and indirectly. A sudden change in the $\mathrm{pH}$ could lead to changes in the enzymes structure and also the toxicity of other compounds.

Christensen [10] states that a $\mathrm{pH}$ far below or higher than the range required by the anaerobes could cause an accumulation of acetate, thereby inhibiting the methanogens and leading to conversion of COD to volatile acids instead of methane $\left(\mathrm{CH}_{4}\right)$ production. 


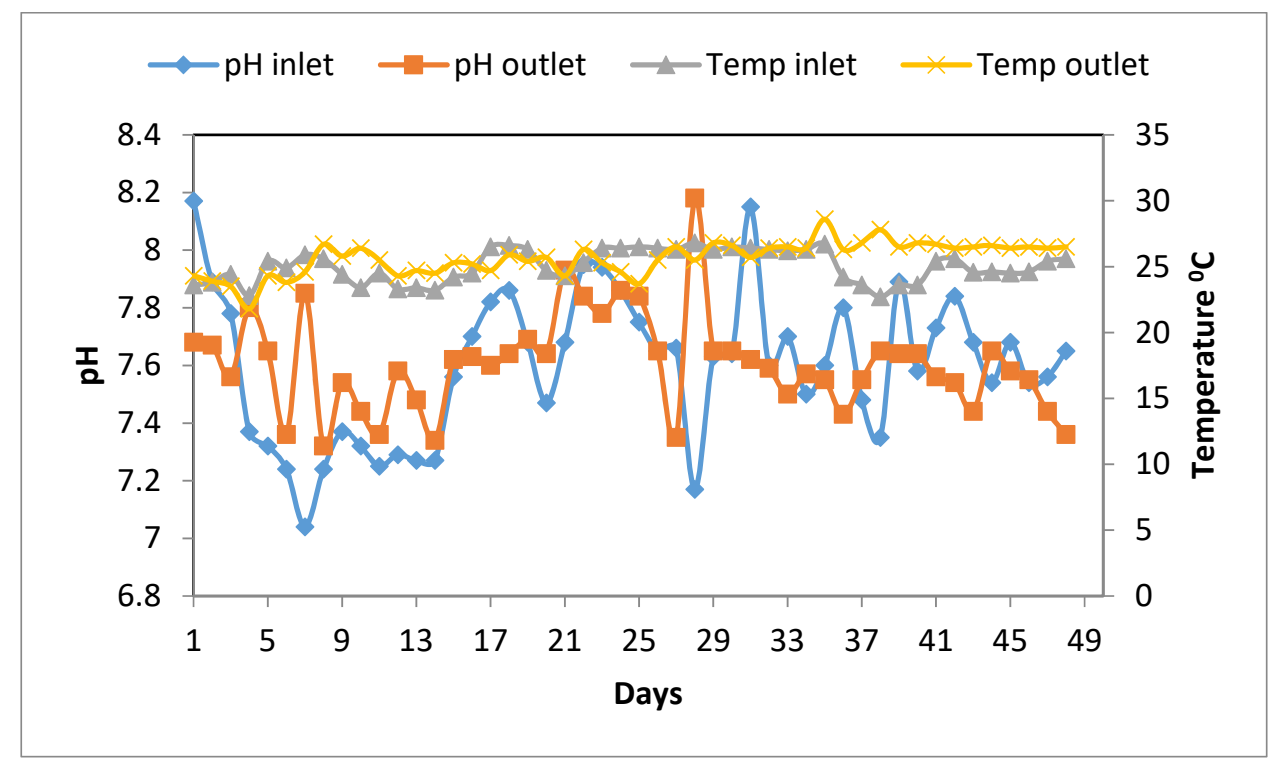

Figure 2: Daily observation of $\mathrm{pH}$ and temperature of the UASB reactor.

Table 1: Composition of the seed sludge and wastewater used in this study and also composition of wastewater from other studies.

\begin{tabular}{|c|c|c|c|c|}
\hline Parameter & $\begin{array}{l}\text { Wastewater } \\
\text { characteristics } \\
\text { before } \\
\text { treatment }\end{array}$ & $\begin{array}{l}\text { Wastewater } \\
\text { characteristics } \\
\text { after } \\
\text { treatment }\end{array}$ & $\begin{array}{l}\text { Percentage } \\
\text { removal of } \\
\text { contaminants } \\
(\%) \\
\end{array}$ & $\begin{array}{l}\text { Wastewater } \\
\text { for another } \\
\text { studies range } \\
{[2]}\end{array}$ \\
\hline COD (mg/l) & 5089 & 653 & 87.2 & $6185-6840$ \\
\hline pH & $7-7.8$ & 7.6 & - & $8.0-8.5$ \\
\hline BOD $_{5}(\mathrm{mg} / \mathrm{l})$ & 1152 & 380 & 67 & $3000-3500$ \\
\hline Turbidity (NTU) & 1572 & 192 & 87.8 & - \\
\hline TSS (mg/l) & 1829 & 533 & 70.9 & $\begin{array}{l}10120 \\
14225\end{array}$ \\
\hline TDS (mg/l) & 1342 & 960 & 28.5 & $6345-7840$ \\
\hline $\begin{array}{l}\mathrm{NH}_{4}^{+} \mathbf{N}(\mathrm{mg} / \mathrm{l} \text { as } \\
\mathrm{N})\end{array}$ & 40 & 20.2 & 39.5 & $650-735$ \\
\hline $\begin{array}{l}\mathrm{NO}_{3}-\mathrm{N}+\mathrm{NO}_{2}-\mathrm{N} \\
(\mathrm{mg} / \mathrm{l})\end{array}$ & 2.8 & 1.5 & 46.4 & - \\
\hline TKN (mg/l) & 40 & 23.5 & 41.3 & $1050-1200$ \\
\hline VSS (mg/l) & 436 & 69.2 & 84.1 & - \\
\hline
\end{tabular}

Table 1 show the results obtained from analysing the raw wastewater and treated effluent, as well as characteristics of slaughterhouse wastewater from other studies. Wastewater from slaughter houses are characterised by high pollution in varying compositions as shown in the table. The wastewater characteristics showed variation from other studies. The reason could be due to variations in operational conditions and as well housekeeping practises. 
Therefore, the result indicates that the water in the present form cannot be discharged without treatment. Observable, the COD and BOD were quite high with a ration of less than 2.5 which indicates that the wastewater can easily be treated using a biological process [3]. The performance of the reactor was measured by analysing other parameters aside from COD which is shown in Table 1 . TSS and VS had a removal of $70-84 \%$. BOD $_{5}$ was at $67 \%$ while turbidity was $87 \%$. Total Kjeldahl Nitrogen (TKN) removal was $41.3 \%$ while $\mathrm{NH}_{4}$ and other nitrates were all below $50 \%$. The results therefore showed improvement on the effluent of the reactor.

\subsection{COD removal rate}

COD in the reactor was measured in its total form on a daily basis for the first three weeks for the start-up and thereafter on a weekly basis. Fig. 3 shows the daily COD removal with different organic loading. The performance of the reactor was based on the removal of COD with different organic loading rates as well as the production of biogas. At the start of the experiment, the organic loading rate (OLR) was $0.2 \mathrm{~kg} C O D / \mathrm{m}^{3} \cdot \mathrm{d}^{-1}$ and was gradually increased to $1.0 \mathrm{~kg} \mathrm{COD} / \mathrm{m}^{3} \cdot \mathrm{d}^{-1}$. Fig. 3 shows the removal rate of COD. A slow removal rate of $39 \%$ was observed at the start of the experiment, but as the experiment progressed, there was a gradual increase which reached a maximum on the $17^{\text {th }}$ day to $86 \%$ for an OLR of $0.2 \mathrm{~kg} \mathrm{COD} / \mathrm{m}^{3} . \mathrm{d}^{-1}$. The low removal rate at the start of the reactor was probably due to the fact that the microorganisms were yet to adapt fully to the seed sludge. With the introduction of the second loading of $0.8 \mathrm{~kg} \mathrm{COD} / \mathrm{m}^{3} \cdot \mathrm{d}^{-1}$, a decrease in the COD from $86 \%$ to $58 \%$ was observed and a similar trend also occurred when the final OLR was introduced. Therefore, at the beginning of introducing a new OLR, there was a corresponding decrease in the removal efficiency but as the system recovers and becomes steady it adapted to the new conditions, and an improvement was recorded.

Results obtained from this study showed some variation when compared with other studies. Venkatesh et al. [12] used a UASB reactor to treat low strength wastewater inoculated with non-granular sludge at a OLR of $1.293 \mathrm{~kg} \mathrm{COD} / \mathrm{m}^{3} \cdot \mathrm{d}^{-1}$ under a period of 84 days. They achieved a 90.8\% COD removal. Similarly, a 92\% SCOD removal at $5.2 \mathrm{~kg}$ SCOD $\mathrm{m}^{3}$.day and HRT of 1.2 days was obtained by Ruiz et al. [13] and 93.4\% COD removal

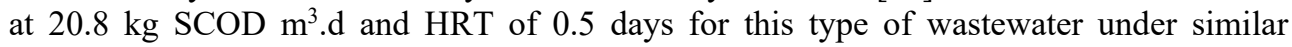
operating conditions [14]. All these studies show some variations. The reasons for the variations in results could be due to a combination of factors such as pre-treatment of wastewater and blood separation in the slaughterhouse which usually accounts for the high pollution load in the wastewater. Others might be due to a high solids content.

\subsection{Biogas production with respect to OLR}

Fig. 3 shows the biogas collected for the period of the experiment. Biogas production refers to both biogas and methane recovered. This is in relation to the theoretical amount expected (from $0.5 \mathrm{~L} / \mathrm{g}$ COD removed). An increase in the gas production was observed from the $5^{\text {th }}$ day, however, with the introduction of a new OLR, the production decreased and thereafter stabilises and then begin to increase. Poor generation of biogas at the initial stage of start-up shows that sludge activity was initially low. The stabilization of the gas production was attributed to the fact that the $\mathrm{pH}$ of the system was at an optimal range of 6.8 to 7.7 and hence no substantial variations in the VFAs. This means then the mutagenesis bacteria were performing optimally [4]. The biogas produced was between $35-67 \%$ which is below the 


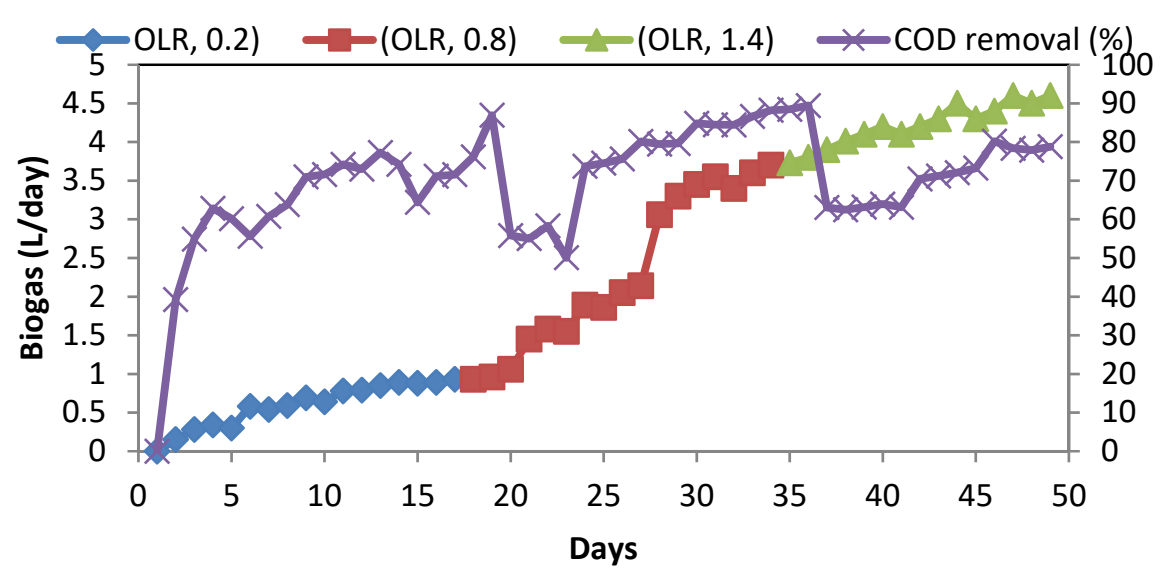

Figure 3: Performance of the UASB reactor treating slaughter house wastewater in terms of COD removal efficiency and daily biogas production.

theoretical value. With regards to the three OLRs, 0.8 produced the highest biogas of 3.45 $\mathrm{L} / \mathrm{d} / \mathrm{g}$ COD. Therefore this was chosen as the best operating OLR for this particular study. A negative correlation between biogas production and increasing OLR has been reported by other researchers. Conclusions that were drawn by those studies stated that further increases in OLR could cause VFA accumulation, which in turn could result in a decrease in the $\mathrm{pH}$ of the reactor, thus inhibiting biogas/methane production [3], [4].

\section{CONCLUSION}

The use of anaerobic digestion was able to reduce the pollution load in a slaughterhouse wastewater and produced biogas which could be used for other purposes. The UASB showed a stable performance with the reduction of CODs of $86 \%$ and a production of $3.45 \mathrm{~L} / \mathrm{d} \mathrm{kg}$ COD of biogas. The optimum OLR was found to be $0.8 \mathrm{~kg} \mathrm{COD} / \mathrm{m}^{3}$.d. It can be concluded from the study that UASB reactors are viable technologies that should be implemented for the treatment of high strength wastewater even those from the slaughterhouses.

\section{ACKNOWLEDGEMENTS}

The authors wish to thank the Durban University of Technology and the National research foundation for funding this research. The authors also wish to acknowledge and thank $\mathrm{Mr}$ Shabangu Khaya, the Laboratory coordinator of the department of Chemical Engineering, Mangosuthu University of Technology for his assistance with the analysis.

\section{REFERENCES}

[1] Gerber, P., Opio, C. \& Steinfeld, H., eds., Poultry production and the environment a review. Poultry in the 21st century: avian influenza and beyond; 2008; Bangkok, Thailand FAO Animal Production and Health Proceedings No. 9, Rome.

[2] Kundu, P., Debsarkar, A. \& Mukherjee, S., Treatment of slaughter house wastewater in a sequencing batch reactor: performance evaluation and biodegradation kinetics. BioMed Research International. 2013, pp. 1-11, 2013. 
[3] Enitan, A.M., Swalaha, F.M., Adeyemo, J. \& Bux, F., Assessment of brewery effluent composition from a beer producing industry In KwaZulu-Natal, South Africa. Fresenius Environmental Bulletin, 23(3), pp. 693-701, 2014.

[4] Chernicharo, C.A., Biological Wastewater Treatment Series: Anaerobic Reactors, IWA Publishing: London, UK, 188 pp., 2007.

[5] Babaee, A. \& Shayegan, J., Effect of organic loading rates (OLR) on production of methane from anaerobic digestion of vegetables waste. World renewable energy congress; Linkoping, Sweden: Bioenergy Technology, 2011.

[6] Adebayo, A., Jekayinfa, S. \& Linke, B., Effects of Organic Loading Rate on Biogas Yield in a Continuously Stirred Tank Reactor Experiment at Mesophilic Temperature. British Journal of Applied Science \& Technology, 11(4), pp. 1-9, 2015.

[7] Chollom, M.N., Rathilal, S ., Pillay,V.L.\& Alfa, D., The applicability of nanofiltration for the treatment and reuse of textile reactive dye effluent. Water $S A, 41(3)$, pp. 398-404, 2015.

[8] APHA-AWWA-WPCF. Standard methods for the examination of water and wastewater. 20th ed., Washington, DC, USA: American Public Health Association/American Water Works Association/Water Environment Federation; 1998.

[9] Aygun, A., Nas, B. \& Berktay, A., Influence of High Organic Loading Rates on COD Removal and Sludge Production in Moving Bed Biofilm Reactor. Environmental Engineering Science, 25(9), pp. 1311-1316, 2008.

[10] Christensen, T., Solid Waste Technology and Management, John Wiley \& Sons, 2011.

[11] Khemkhao, M., Nuntakumjorn, B., Techkarnjanaruk, S. \& Phalakornkule, C., UASB performance and microbial adaptation during a transition from mesophilic to thermophilic treatment of palm oil mill effluent. Journal of Environmental Management. 103(0), pp. 74-82, 2012.

[12] Venkatesh, K.R., Rajendran, M. \& Murugappan, A., Start-Up Of An Upflow Anaerobic Sludge Blanket Reactor Treating Low-Strength Wastewater Inoculated With Non-Granular Sludge. International Refereed Journal of Engineering and Science, 2(5), pp. 46-53, 2013.

[13] Ruiz, I., Veiga, M.C., De Santiago, P. \& Blazquez, R., Treatment of slaughterhouse wastewater in a UASB reactor and an anaerobic filter. Bioresource Technology, 60(3), pp. 251-258, 1997.

[14] Masse, D.I. \& Masse, L., Treatment of slaughterhouse wastewater in anaerobic sequencing batch reactors. Canadian Agricultural Engineering, 42(3), pp. 131, 2000. 